\title{
Autosomal dominant optic atrophy and cataract
}

INSERM

\section{Source}

INSERM. (1999). Orphanet: an online rare disease and orphan drug data base. Autosomal dominant optic atrophy and cataract. ORPHA:67036

Autosomal dominant optic atrophy and cataract (ADOAC) is a form of autosomal dominant optic atrophy (ADOA; see this term) characterized by an early and bilateral optic atrophy leading to insidious visual loss of variable severity, followed by a late anterior and/or posterior cortical cataract. Additional features include sensorineural hearing loss and neurological signs such as tremor, extrapyramidal rigidity and absence of deep tendon reflexes. ADOAC is caused by mutations in the OPA3 gene (19q13.32). 